\title{
The Loyalty of Airport Railink Service Users with Satisfaction Mediation
}

\author{
Aryo Erlangga ${ }^{1, a}$, Widodo ${ }^{2, b}$, Denny Langas Siahaan ${ }^{3, c}$, Prasadja Ricardianto $^{4, d}$, \\ Esti Liana $^{5, e}$ \\ ${ }^{1,2,4}$ Postgraduate Directorate, Trisakti Institute of Transportation and Logistics, Jakarta, Indonesia \\ ${ }^{3}$ Faculty of Transportation System, Trisakti Institute of Transportation and Logistics, Jakarta, Indonesia \\ ${ }^{5}$ Faculty of Management and Business, Trisakti Institute of Transportation and Logistics, Jakarta, Indonesia \\ aAryoerlangga99@gmail.com, bwidmag@gmail.com, ${ }^{\mathrm{c}}$ ladensi@yahoo.com, ricardianto@gmail.com, \\ esti_liana@yahoo.com
}

Corresponding Author: Prasadja Ricardianto

\begin{abstract}
The research objective was to determine the effect of timeliness, convenience, and comfort on the loyalty of Airport Railink service users by mediating the satisfaction of airport train passengers. This research uses a quantitative approach with a survey method and data analysis used descriptive statistics and inferential statistics path analysis. The sample is 100 passengers taken by convenience sampling. The results showed that effect to passenger satisfaction, the results showed that timeliness has a direct effect on passenger satisfaction, ease has a direct effect on passenger satisfaction and convenience has a direct effect on passenger satisfaction. Effect to passenger loyalty, timeliness has a direct effect on passenger loyalty, ease has a direct effect on passenger loyalty, convenience has a direct effect on passenger loyalty and passenger satisfaction has a direct effect on passenger loyalty. Whereas, indirect effect to passenger loyalty, timeliness has an indirect effect on loyalty by mediating passenger satisfaction. Also, ease has an indirect effect on passenger loyalty by mediating passenger satisfaction, and service convenience affects passenger loyalty by mediating passenger satisfaction. The key finding of this research is the management of Railink as an airport train operator issued a specific policy to support the improvement of the Timeliness of airport train services so that passenger satisfaction increases which then has implications for passenger loyalty.
\end{abstract}

Keywords: Timeliness, Ease, Convenience, Satisfaction, Loyalty, Airport Train Passengers

\section{INTRODUCTION}

The economic development of a country or region cannot be separated from the influence of the development of supporting facilities and infrastructure, such as transportation. At the rate of development of each region, transportation plays an important role, because transportation is a means of transportation and a means of moving things from one place to another. Transportation is used to make it easier for humans to carry out daily activities. Business in the field of public transportation services is currently a profitable business prospect, especially in the capital city and its surroundings. People need fast and easy transportation to get it.

Jabodetabek is an area that has experienced a fairly high increase in population mobility. This includes community activities that will go to and from Soekarno-Hatta Airport. However, on the other hand, the provision of transportation facilities to and from the airport is felt to be inadequate. Where the Soekarno Hatta airport train is under the management of PT Railink, a joint venture subsidiary of PT Kereta Api Indonesia (Persero) with PT Angkasa Pura II (Persero). The airport train in Jakarta is the 
second product of PT Railink after the train at Kuala Namu Airport, North Sumatera.

The presence of the Soekarno-Hatta Airport Train makes the competition even tighter from transportation service providers. PT. Railink as the manager of the Soekarno-Hatta Airport Railway must provide quality products and services by the wishes of consumers so that consumers will feel satisfied. Customer satisfaction is the key to the effectiveness of a company, this is considering the satisfaction of consumers will form loyalty. Many factors can affect customer satisfaction and loyalty in using transportation services, one of which is experiential marketing. The findings from the research of (Kumuthadevi, 2013) revealed that the most important factors that determine the satisfaction of train passengers are cleanliness, safety and security, punctuality, behavior towards passengers. The results of research by ( $\mathrm{Li}$ et al., 2017) in China explain that customer loyalty has a positive effect on customer rights. Based on research by (Shiftan et al., 2015) passenger loyalty can measure repeat orders and passenger attitudes towards them. (Kolcaba, 2013) explains that comfort is a condition of having fulfilled basic human needs that are individual and holistic.

However, in the era of service delivery, quality and customer value are factors that influence people's interest in using the desired transportation services, to create free competition among transport operators. The amount of competition caused PT. Railink strives to provide the best service in service to service users by carrying out various strategies to anticipate this competition, including the strategy regarding good handling quality. The target of implementing services from the company is that the management sets quality targets in the form of acknowledgment of the company's service performance as expected by its customers. Reliable, safe service

For the convenience of passengers, at BNI City Station and Airport Station, there are many signboards and information installed, on the top floor of BNI City Station there is an information desk that is always ready to help prospective passengers ask questions or make transactions, at the Airport Station, the information desk is located at downstairs. At BNI City Station there are instructions on the floor in the form of shoe patches that show directions to the platform, exit directions, and so on. The escalator uses a flat escalator (no stairs) making it easier for passengers who carry a lot of goods, with disabilities, and babies who use a stroller. The parking lot for private vehicles can also be used for vehicles staying overnight, its large size and close to the back door and escalators at Sudirman Station, making it easier for prospective passengers to buy tickets.

As for convenience, the Airport Station which consists of 2 floors has a waiting room only on the lower floor, the upper floor is used for offices and places to eat. BNI City Station also consists of 2 floors, the lower floor is used for the waiting room to the platform, while the upper floor is used for offices, VIP waiting rooms (lounge), and places to eat. A comfortable seat with an armrest that can be lifted and a USB port to charge a cellphone, making passengers more relaxed and comfortable. Clean toilets and are located on every train can increase passenger comfort in traveling. Airport train arrivals and departures are on schedule, so passengers don't have to worry about missing their flight from the Airport Station or getting picked up at BNI City Station. Regarding the problems above, the researcher only discusses the effect of timeliness, convenience, and comfort on the satisfaction and loyalty of Railink Airport service users (a case study of airport train passengers on the BNI City StationSoekarno Hatta Airport Station 2019).

Therefore, it can be hypothesized that:

\section{Hypothesis}

H1: Timeliness has a direct effect on customer satisfaction 
$\mathrm{H} 2$ : Convenience has a direct effect on customer satisfaction

H3: Convenience has a direct effect on customer satisfaction

H4: Timeliness has a direct effect on customer loyalty

H5: Ease has a direct effect on customer loyalty

H6: Convenience has a direct effect on customer loyalty

H7: Passenger satisfaction has a direct effect on customer loyalty

H8: Timeliness has a direct effect on customer loyalty by mediating customer satisfaction
H9: Ease has a direct effect on customer loyalty by mediating customer satisfaction H10: Convenience has a direct effect on customer loyalty by mediating customer satisfaction

With such a constellation of relationships between variables, a conceptual framework for this research can be built in the form of a research model on the effect of timeliness, ease, and convenience, on customer loyalty by mediating customer satisfaction (Figure 1).

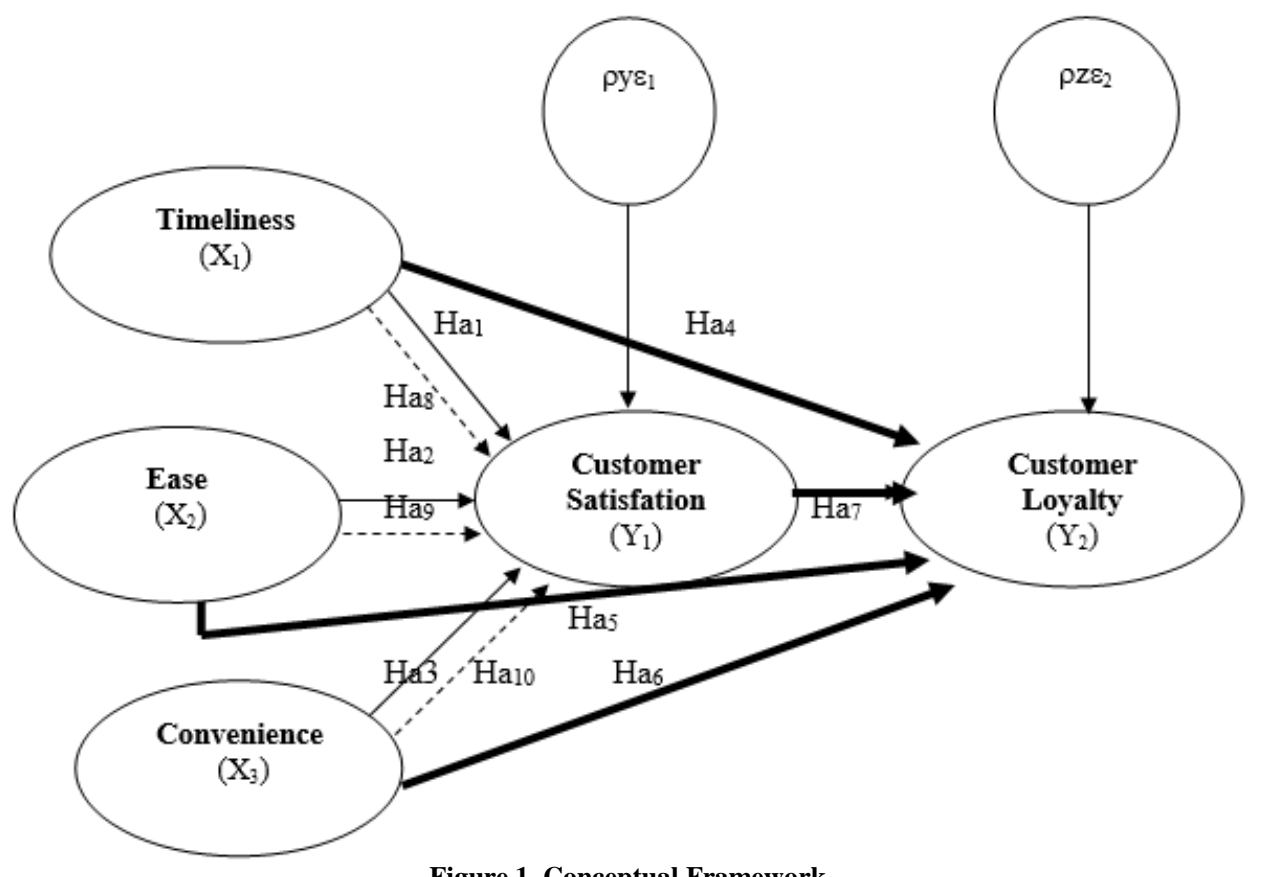

Figure 1. Conceptual Framework

\section{RESEARCH METHODS}

\subsection{Population, Sample and Data Determination Technique}

This study uses a survey method. the target population is the passengers of the Airport Train of BNI City Station-Soekarno Hatta Airport Station during the period January - December 2019 with an average passenger during that period amounting to 4,000 people/year. While the amperage is 100 Passengers of the Airport Train Route of BNI City Station-Soekarno Hatta Airport Station which were taken at nonproportionate random sampling.

\subsection{Analysis Techniques in Partial Least Square Method}

Collecting data using a questionnaire instrument in the form of a Likert scale. The data obtained from the instrument were analyzed using a path analysis approach with the SmartPLS 3 application. To find out and assess the attitudes and perceptions of respondents about the effect of timeliness, ease dan convenience on the loyalty of Railink Airport service users with passenger satisfaction as an intervening variable. 


\section{RESULTS AND DISCUSSION}

\subsection{Hypothesis Testing}

The results of statistical calculations with path analysis processed with the
SmartPLS 3 application to test the research hypotheses obtained path coefficients and $\mathrm{t}$ arithmetic which are described in the path diagram (Figure 2).

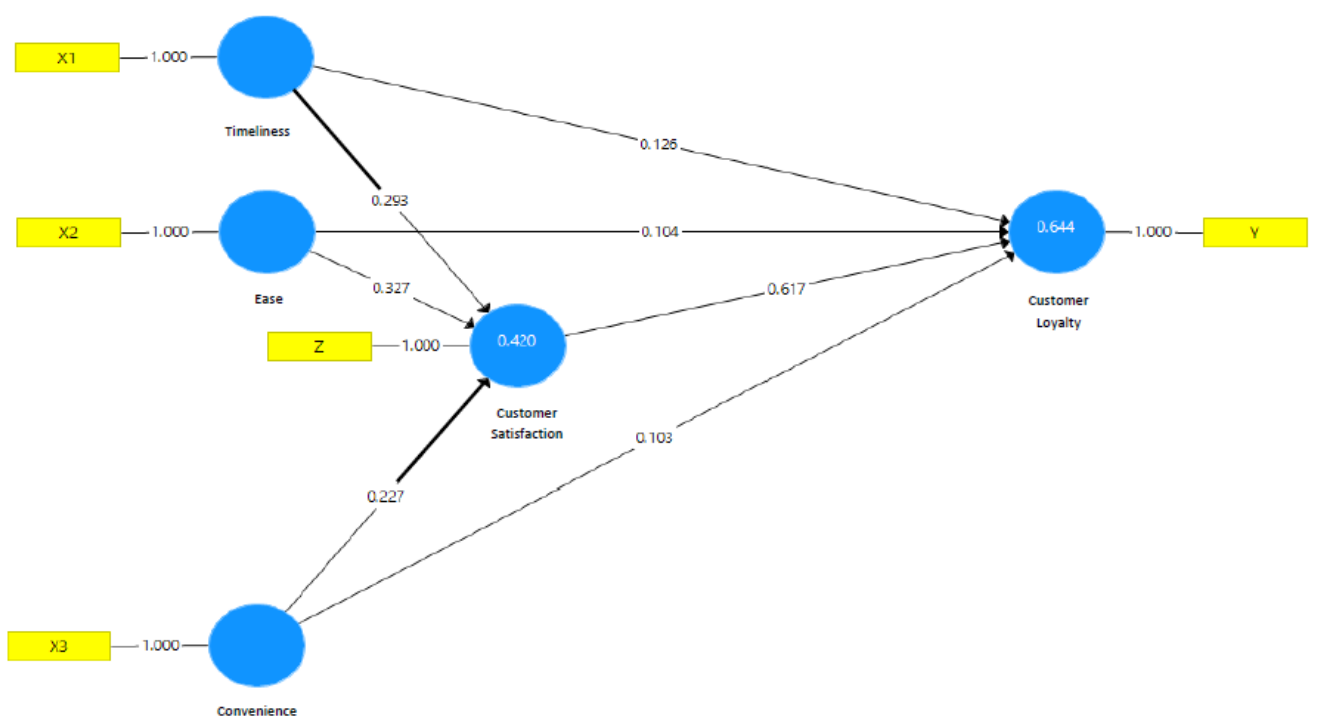

Figure 2. Path Coefficient of Effect of Timeliness, Ease, and Convenience on Satisfaction and Loyalty

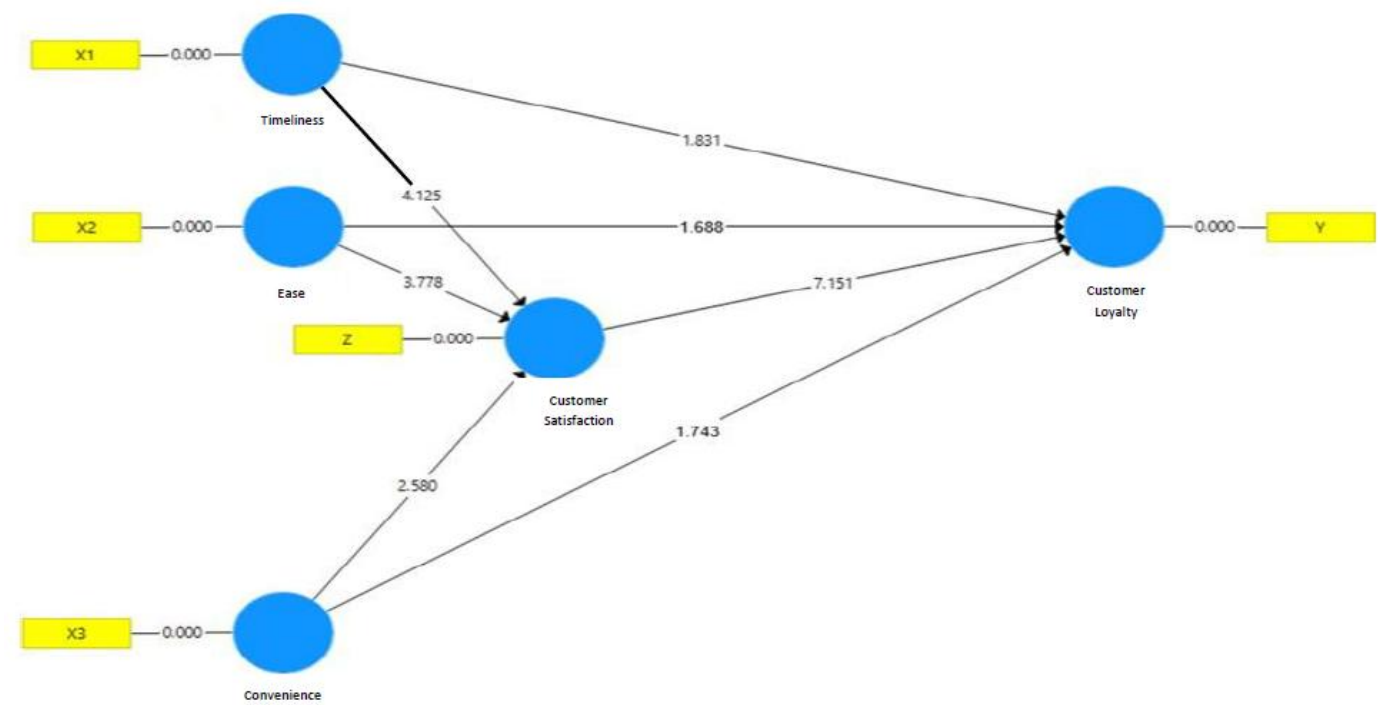

Figure 3. Calculate the Effect of Timeliness, Ease, and Comfort on Satisfaction and Loyalty

Table 1. Path Coefficient Summary and t-Test

\begin{tabular}{l} 
Table 1. Path Coefficient Summary and t-Test \\
\begin{tabular}{|l|l|l|l|}
\hline No & Influence & Path Coefficient & t-statistic \\
\hline 1 & $\mathrm{X} 1-\mathrm{Y} 1$ & 0.293 & $4,125^{* *}$ \\
\hline 2 & $\mathrm{X} 2-\mathrm{Y} 1$ & 0.327 & $3,778^{* *}$ \\
\hline 3 & $\mathrm{X} 3-\mathrm{Y} 1$ & 0.227 & $2,580^{* *}$ \\
\hline 4 & $\mathrm{X} 1-\mathrm{Y} 2$ & 0.126 & $1,831^{*}$ \\
\hline 5 & $\mathrm{X} 2-\mathrm{Y} 2$ & 0.104 & $1,688^{*}$ \\
\hline 6 & $\mathrm{X} 3-\mathrm{Y} 2$ & 0.103 & $1,743^{*}$ \\
\hline 7 & $\mathrm{Y} 1-\mathrm{Y} 2$ & 0.617 & $7,151^{* *}$ \\
\hline 8 & $\mathrm{X} 1-\mathrm{Y} 1-\mathrm{Y} 2$ & 0.181 & $3,863^{* *}$ \\
\hline 9 & $\mathrm{X} 2-\mathrm{Y} 1-\mathrm{Y} 2$ & 0.201 & $3,052^{* *}$ \\
\hline 10 & $\mathrm{X} 3-\mathrm{Y} 1-\mathrm{Y} 2$ & 0.140 & $2,367^{* *}$ \\
\hline
\end{tabular} \\
0* Path coefficient is very significant (t-statistic >t-table on $\alpha=$ \\
*. Significant path coefficient (t-statistic >t-table on $\alpha=0.05)$ \\
\hline
\end{tabular}

3.2. Discussion of Hypothesis Test Results H1. The Effect of the Timeliness on the Customer Satisfaction

The results of this study empirically prove that timeliness has a positive and very significant effect on customer satisfaction, with an indication of the path coefficient value of 0.293 and the value of t-statistic $=$ $4,125>$ t-table value $=2,364$. This means that the departure and arrival of airport trains according to a predetermined schedule can increase passenger 
satisfaction. In other words, the departure and arrival of trains according to the schedule, both the Timeliness of arrival, departure, preparation and stopping at the station, as well as Timeliness compared to other modes of transportation can stimulate feelings of satisfaction among passengers which comes from comparing their impressions on the timeliness of train services, airport fire, at least when measured by indicators: expectation, subjective disconfirmation, and performance outcomes. Satisfaction can be affected by timing. Research by (Lisnasari et al., 2016) shows that Timeliness has a significant effect on Customer Satisfaction. (Apriyadi, 2017; Widodo et al., 2015) also shows the timeliness of service has a significant effect on customer satisfaction.

Therefore, the result of this study is in line with theoretical studies and the result of previous related studies. It means that timeliness has a positive and significant affects customer satisfaction.

\section{H2. The Effect of the Ease on the Customer Satisfaction}

The results of this study also indicate that ease has a positive and very significant effect on customer satisfaction, with path coefficient value $=0.327$ and $\mathrm{t}$-statistic $=$ $3.778>$ t-table value $=2.364$. This means that various ease in using airport train services can increase passenger satisfaction. In other words, the ease obtained by airport train passengers as providers of ground transportation services which includes indicators: clear and easy to understand, does not require much effort to interact, easy to use, and easy to operate can encourage feelings of satisfaction among passengers at least when measured with indicators: expectation, subjective disconfirmation and performance outcomes. Research result by (Deborah, 2018) also prove that the ease of service has a significant effect on customer satisfaction. Research by (Prabaningtyas, 2014) shows that the convenience variable has a positive and significant effect on customer satisfaction. Other research results by (Anugrah, 2020; Mandasari \& Giantari, 2017) show that ease of use has a significant effect on customer satisfaction.

Therefore, the result of this study is in line with theoretical studies and the result of previous related studies. It means that ease has a positive and significant affects customer satisfaction.

\section{H3. The Effect of the Convenience on the Customer Satisfaction}

The results of this study also prove that convenience has a positive and very significant effect on customer satisfaction, with the path coefficient value $=0.227$ and $\mathrm{t}$-statistic $=2,580>\mathrm{t}$-table value $=2,364$. This means that the convenience of using airport train services can increase passenger satisfaction. In other words, the convenience of airport train services that provide a comfortable feeling for passengers, with indicators: the convenience of access, the convenience of transactions, convenience of benefits, and comfort after obtaining benefits can encourage the emergence of feelings of satisfaction among passengers at least when measured by indicators: expectation, subjective disconfirmation, and performance outcomes. Research result by (Ruswinda et al., 2019) also prove that the ease of service has a significant effect on customer satisfaction. The results of other studies indicate that the service convenience dimension has a positive impact on customer satisfaction (Kaura et al., 2015). In addition, customer satisfaction is also a mediating variable. The results of the study by (Srivastava \& Kaul, 2014) stated that the first time to examine four constructs namely, social interaction, convenience, customer satisfaction and customer experience using these variables together in the same model. In addition, satisfaction is influenced by convenience, (Surbakti \& Bombongan, 2017) in their research, found the characteristics of train and bus users from Medan to Kuala Namu Airport and passengers will choose both modes of transportation. 
Therefore, the result of this study is in line with theoretical studies and the result of previous related studies. It means that convenience has a positive and significant affects customer satisfaction.

\section{H4. The Effect of the Timeliness on the Customer Loyalty}

The results of this study also reveal empirical facts that timeliness has a positive and significant effect on customer loyalty, with an indication of path coefficient value $=0.126$ and $\mathrm{t}$-statistic $=1.831>\mathrm{t}$-table value $=1.660$. This means that the departure and arrival of airport trains according to a predetermined schedule can increase passenger loyalty. In other words, the departure and arrival of trains according to schedule, both Timeliness of arrival, departure, preparation, and stopping at the station, as well as timeliness compared to other modes of transportation encourage passenger loyalty as a manifestation of the loyalty of airport train passengers which is presented in the behavior of making purchases online. regularly, buy outside the product or service line, refer the company's products to others, as well as showing immunity from the attractiveness of similar products from competitors. Studies conducted (Setiawan, 2014) also show the timeliness of service has a significant effect on customer loyalty.

Therefore, the result of this study is in line with theoretical studies and the result of previous related studies. It means that timeliness has a positive and significant affects customer loyalty.

\section{H5. The Effect of the Ease on the Customer Loyalty}

The results of this study also found that ease has a positive and significant effect on customer loyalty, with an indication of the path coefficient value $=0.104$ and $\mathrm{t}$ statistic $=1.688>$ t-table value $=1.660$. This means that various ease in using airport train services can increase passenger loyalty. In other words, the ease obtained by airport train passengers as providers of ground transportation services which includes indicators: clear and easy to understand, does not require much effort to interact, easy to use, and easy to operate can encourage increased passenger loyalty as a manifestation of the loyalty of train passengers. airports that are presented in the behavior of making regular purchases, buying outside the product or service line, referencing the company's products to others, as well as showing immunity from the attractiveness of similar products from competitors. Results of research conducted (Arief \& Khabibah, 2019) also show the ease of service has a significant influence on customer loyalty. Other research results by (Anugrah, 2020) show that ease of use has a significant effect on and customer loyalty.

Therefore, the result of this study is in line with theoretical studies and the result of previous related studies. It means that ease has a positive and significant affects customer loyalty.

\section{H6. The Effect of the Convenience on the Customer Loyalty}

The results of this study also found that convenience has a positive and significant effect on customer loyalty, with an indication of the path coefficient value $=$ 0.103 and tcount $=1.743>\mathrm{t}$-table value $=$ 1.660. This means that the convenience of using airport train services can increase passenger loyalty. In other words, the convenience of airport train services that provide a comfortable feeling for passengers, with indicators: the convenience of access, the convenience of transactions, convenience of benefits, and convenience after obtaining benefits can encourage increased passenger loyalty as a manifestation of loyalty of airport train passengers which is presented in behavior. Make regular purchases, buy outside the product or service line, refer company products to others, as well as showing immunity from the attraction of similar products from competitors. The results of other studies indicate that the service convenience dimension has a positive 
impact on customer loyalty (Kaura et al., 2015). Results of research conducted by (Sanjaya, 2018) also show that service convenience has a significant influence on customer loyalty. When the indicators of the convenience of access, the convenience of transactions, convenience of benefits, and convenience after obtaining benefits are well-conditioned it will increase loyalty.

Therefore, the result of this study is in line with theoretical studies and the result of previous related studies. It means that convenience has a positive and significant affects customer loyalty.

\section{H7. The Effect of the Customer Satisfaction on the Customer Loyalty}

The results of this study also found that customer satisfaction has a positive and very significant effect on customer loyalty, with an indication of path coefficient value $=0.617$ and $\mathrm{t}$-statistic $=7.151>\mathrm{t}$-table value $=2.364$. This means that passenger satisfaction can encourage their loyalty to use airport train services. In other words. Passenger satisfaction that comes from comparing their impressions of airport train services which are manifested in the indicators: expectation, subjective disconfirmation, and performance outcomes can increase passenger loyalty as a manifestation of airport train passenger loyalty. Presented in the behavior of making regular purchases, buying outside the product or service line, refer the company's products to others, as well as showing immunity from the attractiveness of similar products from competitors. Results of research conducted by (Thanaraju et al., 2019; Wang et al., 2018), as well as (SzeSiong \& Aksan, 2018) also show that satisfaction has a significant influence on customer loyalty. Research by (Mandasari \& Giantari, 2017; Yulisetiarini et al., 2018) shows that satisfaction affects consumer loyalty. When indicators of customer satisfaction, namely expectation, subjective disconfirmation, and performance outcomes are well-conditioned, it will increase loyalty. This is in line with the statement
(Maylina, 2003) that consumers will be loyal or loyal to a brand if he gets satisfaction from the brand.

Therefore, the result of this study is in line with theoretical studies and the result of previous related studies. It means that customer satisfaction has a positive and significant affects customer loyalty.

\section{H8. The Effect of the Timeliness on the Customer Loyalty by mediating the Customer Satisfaction}

The results of this study also found that timeliness has a positive and very significant effect on customer loyalty by mediating customer satisfaction, with an indication of path coefficient $=0.181$ and $\mathrm{t}-$ statistic value of $3.863>$ t-table value $=$ 2.364. This finding shows that the timeliness of airport train services can lead to a sense of satisfaction among passengers, which in turn has implications for their loyalty. When the departure and arrival of airport trains are according to a predetermined schedule, it can increase passenger satisfaction, and then they are loyal to continue using the services of the train, airport, which is reflected in the behavior of making regular purchases, buying outside the product or service line, referring company products to others.

\section{H9. The Effect of the Ease on the Customer Loyalty by mediating the Customer Satisfaction}

The results of this study also found that ease has a positive and very significant on customer loyalty by mediating customer satisfaction, with an indication of path coefficient $=0.201$ and $\mathrm{t}$-statistic $=3.052>$ $\mathrm{t}$-table value $=2.364$. This finding shows that the convenience of airport train services can lead to a sense of satisfaction among passengers, which in turn has implications for their loyalty. When the ease of service provided by the airport train manager meets passenger expectations, it can stimulate passenger satisfaction, and then they are loyal to continue using airport train services, which is reflected in the behavior of making 
regular purchases, buying outside the product, or service line, referencing products company to others, as well as showing immunity from the attractiveness of similar products from competitors.

\section{H10. The Effect of the Convenience on the Customer Loyalty by mediating the Customer Satisfaction}

Finally, the results of this study also found that convenience has a positive and very significant on customer loyalty by mediating customer satisfaction, with an indication of the path coefficient value $=$ 0.140 and t-statistic $=2,367>$ t-table value $==2,364$. This finding shows that the customer convenience of airport train services can lead to a sense of customer satisfaction among passengers so which then has implications for their loyalty. When the convenience of the services provided by the airport train manager meets passenger expectations, it can increase passenger satisfaction so that they are then loyal to continue using airport train services, which is reflected in the behavior of making regular purchases, buying outside the product or service line, referencing products. company to others.

Especially effect to passenger satisfaction, the results showed that timeliness has a direct effect on passenger satisfaction, ease has a direct effect on passenger satisfaction and convenience has a direct effect on passenger satisfaction. Effect to passenger loyalty, timeliness has a direct effect on passenger loyalty, ease has a direct effect on passenger loyalty, convenience has a direct effect on passenger loyalty and passenger satisfaction has a direct effect on passenger loyalty. Whereas, indirect effect to passenger loyalty, timeliness has an indirect effect on loyalty by mediating passenger satisfaction. Also, ease has an indirect effect on passenger loyalty by mediating passenger satisfaction, and service convenience affects passenger loyalty by mediating passenger satisfaction.

\section{CONCLUSION}

The management of Railink as an airport train operator issued a specific policy to support the improvement of the Timeliness of airport train services so that passenger satisfaction increases which then has implications for passenger loyalty. The policy should consider indicators of Timeliness of arrival, Timeliness of departure, Timeliness of preparation and stopping at stations, as well as Timeliness of trains compared to other modes of transportation with the same purpose, especially crucial aspects reflected in the items of the accuracy questionnaire. less than the maximum response time by airport train passengers.

\section{Acknowledgement: None}

\section{Conflict of Interest: None}

\section{Source of Funding: None}

\section{REFERENCES}

1. Anugrah, F. T. (2020). Effect of Promotion and Ease of Use on Customer Satisfaction and Loyalty on OVO Application Users. Quantitative Economics and Management Studies, 1(1), 44-50. https://doi.org/10.35877/454RI.qems77

2. Apriyadi, D. (2017). Analisis pengaruh ketepatan waktu, fasilitas dan harga tiket terhadap kepuasan penumpang kereta api di stasiun Purwosari. MAGISTRA, 29(99).

3. Arief, M. S. I., \& Khabibah, U. (2019). Analisis Pengaruh Kemudahan Dan Kepercayaan Penggunaan E-Commerce Shopee Terhadap Loyalitas Konsumen. Jurnal Aplikasi Bisnis, 5(1), 161-164.

4. Debora, L. (2018). Pengaruh Kualitas Jasa, Kemudahan Transaksi, Dan Promosi Terhadap Loyalitas Konsumen Pt Xyz: Kepuasan Konsumen Sebagai Variabel Mediasi. Jurnal Manajemen Bisnis Dan Kewirausahaan, 2(6).

5. Kaura, V., Durga Prasad, C. S., \& Sharma, S. (2015). Service quality, service convenience, price and fairness, 
customer loyalty, and the mediating role of customer satisfaction. International Journal of Bank Marketing, 33(4), 404422. https://doi.org/10.1108/IJBM-042014-0048

6. Kolcaba. (2013). Developing a scale to measure customer loyalty. Procedia Economics and Finance, 3, 623-628.

7. Kumuthadevi, K. (2013). Service Quality of South Indian Railway- Determinants of Passenger Satisfaction in Trains. International Journal of Business and Management, 2(2).

8. Li, X., Ma, B., \& Zhou, C. (2017). Effects of customer loyalty on customer entitlement and voiced complaints. The Service Industries Journal, 37(13-14), 858-874.

https://doi.org/10.1080/02642069.2017.13 60290

9. Lisnasari, N., Rudi, A., \& Pratiwi, D. (2016). Analisis pengaruh faktor ketepatan waktu dan tarif pengiriman barang atau jasa terhadap kepuasan pelanggan (Studi Kasus Pada PT Kerta Gaya Pusaka). Jurnal Progresif Manajemen Bisnis, 13(2), 33-41.

10. Mandasari, I. A. C. S., \& Giantari, I. G. A. K. (2017). Pengaruh perceived usefulness, perceived ease of use, dan kualitas layanan terhadap kepuasan untuk membangun loyalitas. E-Jurnal Ekonomi Dan Bisnis Universitas Udayana, 10(6), 3637-3664.

11. Maylina, W. (2003). Faktor-Faktor Yang Mempengaruhi Kesetiaan terhadap Merek pada Konsumen Pasta Gigi Pepsodent di Surabaya. Jurnal Ventura, 6(1), 98-115.

12. Prabaningtyas, K. A. (2014). Pengaruh Kualitas Layanan, E-Factor dan Kemudahan Terhadap Loyalitas Pelanggan dengan Mediasi Kepuasan Pelanggan. Jurnal Ilmu Manajemen (JIM), 2(3).

13. Ruswinda, E., Arifin, R., \& Priyono, A. A. (2019). Pengaruh Faktor Harga, Keamanan, Kenyamanan Dan Ketepatan Waktu Terhadap Pembelian Tiket Kereta Api Ekonomi Ac Penataran Jurusan Surabaya-Malang- Blitar (Studi Kasus Pada Penumpang Kereta Api Ekonomi
Penataran Di Stasiun Kota Baru Malang). Jurnal Ilmiah Riset Manajemen, 8(07).

14. Sanjaya, L. J. (2018). Hubungan Antara Kenyamanan Pelayanan Dengan Loyalitas Pelanggan: Studi Pada Mahasiswa Universitas Diponegoro Pengguna Layanan Go-Jek Di Semarang. Jurnal Empati, 6(4), 149-156.

15. Setiawan, M. A. (2014). Analysis of the effect of timeliness, price and product quality on the level of customer satisfaction and loyalty at the printing company CV Aladin. [Thesis] Univeristas Dian Nuswantoro: Semarang.

16. Shiftan, Y., Barlach, Y., \& Shefer, D. (2015). Measuring passenger loyalty to public transport modes. Journal of Public Transportation, 18(1), 7.

17. Srivastava, M., \& Kaul, D. (2014). Social interaction, convenience and customer satisfaction: The mediating effect of customer experience. Journal of Retailing and Consumer Services, 21(6), 10281037.

https://doi.org/10.1016/j.jretconser.2014.0 4.007

18. Surbakti, M., \& Bombongan, C. (2017). Characteristic of Modal Choice Preference between Bus and Train from Medan to Kuala Namu Airport. IOP Conference Series: Materials Science and Engineering, 180(1).

19. Sze-Siong, C., \& Aksan, A. (2018). Users' Satisfaction with Mass Rapid Transit and the Effect of Different Genders and Trip Purposes. International Journal of Academic Research in Business and Social Sciences, 8(15), 131-145. https://doi.org/DOI: 10.6007/IJARBSS/v8-i15/5097

20. Thanaraju, P., Khan, P. A. M., Sivanathan, S., \& Juhari, H. N. (2019). Passengers' Satisfaction towards Railway Facilities (RAILQUAL in the Central Region). International Journal of Recent Technology and Engineering (IJRTE), $8(2)$.

21. Wang, Y., Zhang, Z., \& Sun, H. (2018). Assessing customer satisfaction of urban rail transit network in Tianjin based on intuitionistic fuzzy group decision model. 
Discrete Dynamics in Nature and Society, 2018.

22. Widodo, S. A., Fathoni, A., \& Haryono, A. T. (2015). Pengaruh Kualitas Pelayanan, Tarif Dan Ketepatan Waktu Terhadap Kepuasan Pelanggan. Journal of Management, 1(1), 1-11.

23. Yulisetiarini, D., Indraningrat, K., \& Hijriah, H. (2018). Pengaruh Nilai Pelanggan, Kualitas Layanan, Harga Dan Kepercayaan Terhadap Loyalitas Melalui
Kepuasan Penumpang Kereta Api Sri Tanjung Jember-Yogyakarta PT. KAI DAOP IX Jember. UNEJ E-Proceeding.

How to cite this article: Erlangga A, Widodo, Siahaan DL et.al. The loyalty of Airport Railink service users with satisfaction mediation. International Journal of Research and Review. 2021; 8(8): 712-721. DOI: https://doi.org/10.52403/ijrr.20210894 